Case report

\title{
Double integration band of HTLV-1 in a young patient with infective dermatitis who developed an acute form of adult T-cell leukemia/lymphoma
}

\author{
Pedro D. Oliveira ${ }^{\mathrm{a}}$, Marcelo Magalhães ${ }^{\mathrm{b}}$, Juliana M. Argolo ${ }^{\mathrm{b}}$, Achiléa L. Bittencourt ${ }^{\mathrm{c}, \mathrm{d}}$, Lourdes Farre ${ }^{\mathrm{b}, *, \mathrm{~d}}$ \\ a Service of Dermatology, Complexo Hospitalar Universitário Prof. Edgard Santos, Federal University of Bahia, Rua Dr. Augusto Viana, s/n, Canela, CEP: 40.110-060, \\ Salvador, Bahia, Brazil \\ b Laboratory of Experimental Pathology (LAPEX), CPQGM-FIOCRUZ, Bahia, Rua Waldemar Falcão 121, Candeal, CEP: 40296-710, Salvador, Bahia, Brazil

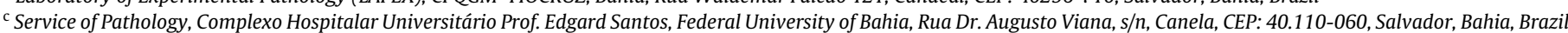

\section{A R T I C L E I N F O}

Article history:

Received 3 July 2012

Received in revised form 17 October 2012

Accepted 18 October 2012

Keywords:

HTLV-1

Adult T-cell leukemia/lymphoma

Infective dermatitis

Proviral integration

\begin{abstract}
A B S T R A C T
Few cases of acute adult T-cell leukemia/lymphoma (ATL) have been diagnosed in young patients. This report is the first to describe a young girl with infective dermatitis associated with HTLV-1 that progressed to acute ATL with Southern blot hybridization and gamma-TCR-rearrangement revealing a monoclonal pattern with two copies of the provirus.
\end{abstract}

(C) 2012 Elsevier B.V. All rights reserved.

\section{Why this case is important?}

Adult T-cell leukemia/lymphoma (ATL) generally occurs after a long period of human T-cell lymphotropic virus type 1 (HTLV1) infection. ${ }^{1}$ However, rare cases of ATL have been described in patients with infective dermatitis associated with HTLV-1 (IDH) prior to 20 years of age. ${ }^{2-4}$ Only one of these patients, already in remission of IDH, developed the acute form of ATL. ${ }^{3}$

To the best of our knowledge, this report represents the first case of IDH associated with acute ATL with a double band of HTLV-1 integration.

\section{Case report}

A 19-year-old girl born and living in Bahia, Brazil presented at the Federal University of Bahia Teaching Hospital with recurrent eczema on her scalp, retroauricular area, face and neck that had been present since she was three years old. She reported a history of papules all over her body for the past six months. She informed that she had used oral corticosteroids to treat the lesions. Polymerase

\footnotetext{
* Corresponding author at: Laboratory of Experimental Pathology, Centro de Pesquisa Gonçalo Moniz-Fundação Oswaldo Cruz. Rua Waldemar Falcão, 121, Brotas - CEP: 40.295-001, Salvador, Bahia, Brazil. Tel.: +55 7131762228; fax: +55 7131762228 .

E-mail address: lfarre@bahia.fiocruz.br (L. Farre).

$d$ These authors contributed equally to this study.
}

chain reaction (PCR) was performed using DNA from peripheral blood mononuclear cells (PBMC) to confirm the presence of HTLV1 infection. ${ }^{5}$ Physical examination revealed erythematous, scaly and crusty lesions on the scalp and retroauricular region associated with disseminated erythematous macules and papules, some of which were ulcerated. The palms of her hands and the soles of her feet were also affected. Most of the papules were concentrated on her forehead and on the back of her neck (Fig. 1). She also presented with blepharoconjunctivitis and hepatosplenomegaly. She reported having lost $3 \mathrm{~kg}$ of body weight. Laboratory tests showed marked lymphocytosis (428,000 lymphocytes $/ \mathrm{mm}^{3}$ ), neutrophilia, eosinophilia, thrombocytopenia and anemia. The presence of $23 \%$ of atypical cells was found, including $8 \%$ of flower cells in smears of peripheral blood. There was hypercalcemia and a marked increase in lactate dehydrogenase (LDH) (7 times the upper normal limit). Peripheral blood was acquired in FACScalibur (Becton-Dickinson, San Jose, CA, USA) for immunophenotyping, ${ }^{6}$ which showed $97 \%$ of small and large CD2+ T lymphocytes, as well as CD3+, CD4+, CD7-, CD8- and CD25+ lymphocytes, suggesting a lymphocytic proliferative disease, compatible with ATL. ${ }^{6}$ Bone marrow biopsy showed no infiltration by malignant cells. Skin biopsy revealed atypical medium and large lymphocytes infiltrating the upper and middle dermis. The immunohistochemical study was performed on formalin-fixed, paraffin-embedded sections using a standard streptavidin-biotin-peroxidase technique, ${ }^{7}$ and revealed $\mathrm{CD} 2+, \mathrm{CD} 3+, \mathrm{CD} 4+, \mathrm{CD} 5-, \mathrm{CD} 8-, \mathrm{CD} 20-, \mathrm{CD} 25+$ and CD79acells, the same phenotype of peripheral blood. A marked epidermotropism with Pautrier's abscesses was also observed (Fig. 2). 
A

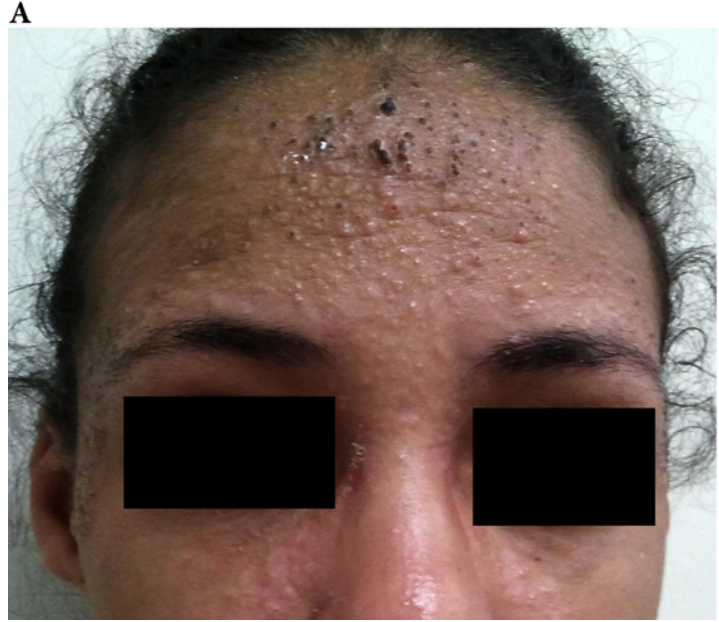

B

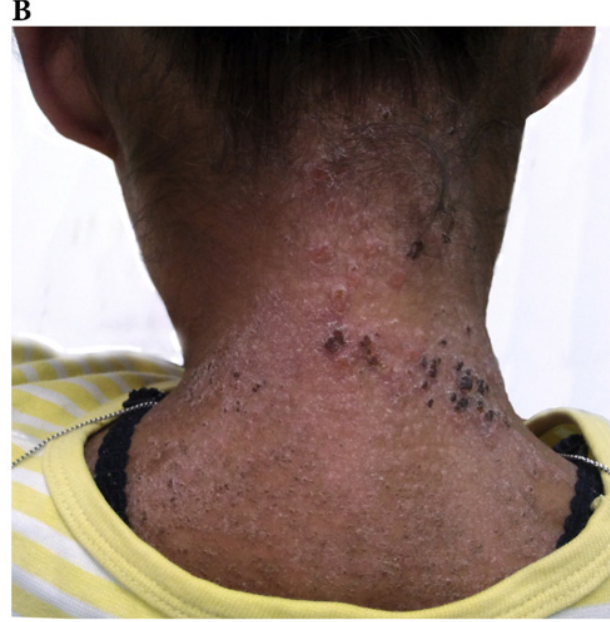

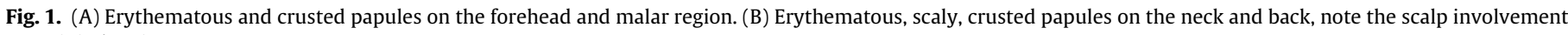
at occipital region.

A

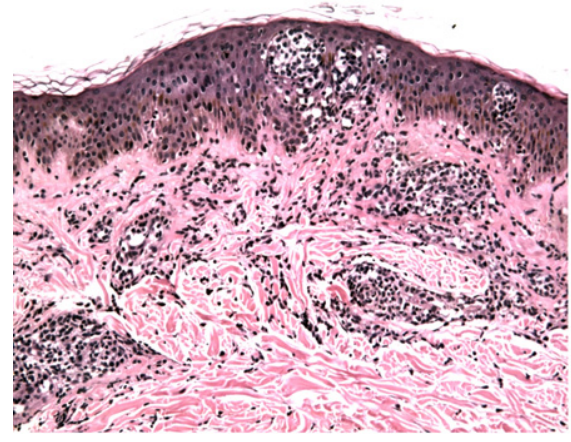

B

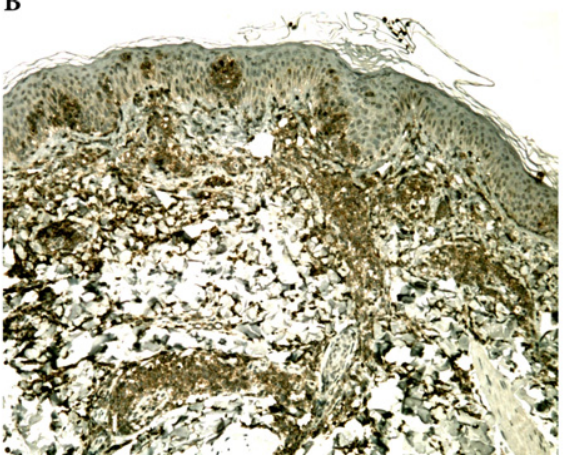

C

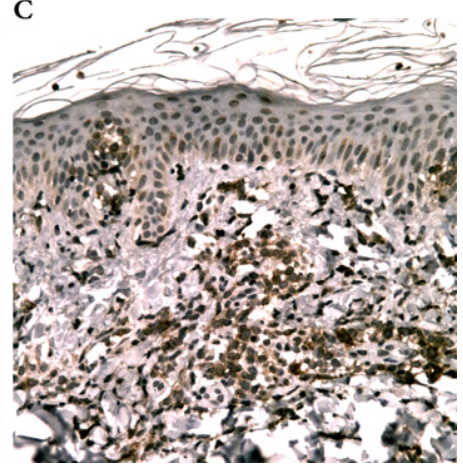

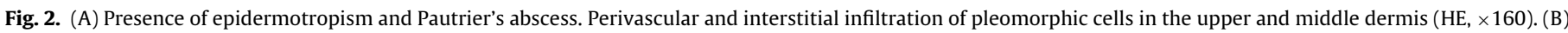
CD4+ cells in epidermis and dermis $(\times 100)$. (C) CD25+ cells in epidermis and dermis $(\times 250)$.

The proliferative index, as evaluated by Ki-67 expression, was $70 \%$. The histological pattern was similar to that of peripheral Tcell lymphoma, unspecified. Proviral integration was evaluated by Southern blot using EcoRI digestion of DNA extracted from PBMC; the used probes were derived from HTLV-1 fragments, ${ }^{8}$ resulting in the appearance of two bands with equal densities over $9 \mathrm{~kb}$ (Fig. 3 ). T-cell receptor gamma-chain gene rearrangement, as assessed by PCR in a skin biopsy, showed a monoclonal pattern. HTLV-1 proviral load was estimated as 230 copies/100 PBMC. ${ }^{9}$ The final diagnosis was IDH that had progressed to acute ATL.

Treatment was initiated with interferon-alfa (IFN) associated with zidovudine (AZT) but the patient died of respiratory failure 10 days later. An investigation was made to detect the presence of genetic alterations in ATL cells. No point mutations were found in exons 5-9 of the TP53 gene, in exons $1-3$ of the p16INKA gene or in exons 1 and 2 of the p15INKA gene. ${ }^{10}$ Furthermore, no microsatellite alterations (microsatellite instability or loss of heterozygosity) were found in the D10S190, D10S191, D11S1391 or D18S21 loci analyzed using a semi-automatic technique. As normal tissue controls were used the DNA extracted from the patient's nails and oral mucosa. ${ }^{11}$

\section{Other similar and contrasting cases}

There have been rare isolated reports on the progression of IDH to ATL in young patients. ${ }^{2-4}$ In one case, the patient with active IDH had sequentially developed HTLV-1-associated

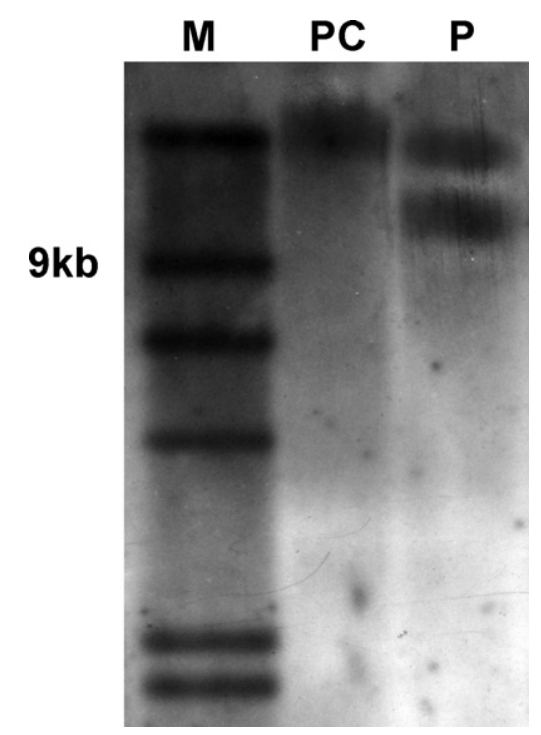

Fig. 3. See a double band pattern of proviral integration, evaluated by Southern blot using EcoRI digestion of DNA extracted from PBMC. The used probes were derived from HTLV-1 virus fragments. The positive control was an acute ATL case with proviral monoclonal integration (Southern blot and inverse PCR). M: marker; PC: positive control; P: patient. 
myelopathy/tropical spastic paraparesis (HAM/TSP) and smoldering ATL. ${ }^{2}$ In that patient, monoclonal integration of HTLV-1 proviral DNA revealed only one band. ${ }^{2}$ Another case, a 20 year-old patient developed a pattern of acute ATL after remission of IDH. ${ }^{3}$ A third case of a 17 year-old girl with simultaneous IDH and chronic ATL was observed in Senegal. ${ }^{4}$ Besides, LaGrenade et al. reported two cases of IDH before the age of 20 years with persistent lymphocytosis and polylobulated lymphocytes in peripheral blood, without tissue infiltration, serological evaluation and molecular studies, considered at that time as pre-ATL cases. ${ }^{12}$

This is the second case, which we are aware, of IDH in a young patient in whom the condition progressed to acute ATL, and the first associated to a double band on Southern blot hybridization assay for HTLV-1 integration.

\section{Discussion}

In the current case, the age of the patient at onset of IDH, the distribution and morphology of the skin lesions and the association with blepharoconjunctivitis correspond to features that have been reported in the majority of cases of IDH. ${ }^{13}$

The presence of flower cells in peripheral blood in association with severe lymphocytosis, high LDH levels and hypercalcemia facilitated the diagnosis of acute ATL in this patient, according to Shimoyama classification. ${ }^{14}$

The histological findings (large cells and high proliferative index) are in accordance with the aggressiveness of disease. ${ }^{1}$

The presence of monoclonal integration of HTLV-1 proviral DNA was one more piece of evidence confirming that in this patient leukemia/lymphoma was indeed related to HTLV-1. ${ }^{15}$ The presence of a double band on Southern blot most probably corresponds to double HTLV-1 integration in one ATL clone rather than the occurrence of double ATL clones. ${ }^{8}$ In support of this hypothesis, monoclonality of T-lymphocytes was found in the T-cell receptor rearrangement when gamma-chains were analyzed. In Japan, the occurrence of a double band on Southern blot has been found more often in cases of acute ATL rather than in the chronic and smoldering types. $^{8}$

The most frequent point mutations reported in acute ATL were located in the TP53 gene. ${ }^{10}$ Moreover, a study including 54 microsatellites showed that the loci studied in this paper are those most commonly found to be altered in cases of acute ATL. ${ }^{11}$ However, these results in the present case showed that the aggressiveness of the condition was not associated with these genetic alterations. Notwithstanding, other genetic and epigenetic alterations should be investigated in the current case.

Unlike the present case, ATL generally occurs after a long period of HTLV-1 infection during which genetic and epigenetic alterations may accumulate. ${ }^{10}$ As genetic alterations evaluated were not observed in this case, at least in the regions studied, aggressiveness may be related to the presence of two copies of the provirus interrupting host sequences.

Acute ATL may respond well to the association of AZT and IFN, unfortunately, the patient came to the hospital very late, six months after onset of the disease, and her prognosis was poor (elevated LDH levels, marked thrombocytopenia, neutrophilia and eosinophilia). ${ }^{15}$

The current case supports the hypothesis that the relationship between IDH and ATL is very close, at least in the population living in the Brazilian state of Bahia, where $37.5 \%$ of the patients with ATL affecting the skin were found to have had a history of severe eczema in childhood, consistent with IDH. ${ }^{16}$ Recently, flower cells were detected in $10 \%$ of children and adolescents with IDH. ${ }^{17}$ Considering that the HTLV-1 proviral load is high in IDH, ${ }^{17}$ these aspects may be considered indicative of a greater risk for the development of ATL compared to the finding of these cells in asymptomatic adult carriers.

These data highlight the importance of monitoring cases of IDH, even after complete remission of the disease; since patients may go on to develop an aggressive type of ATL, even in adolescence and early adulthood. Patients should be followed up regularly, and clinical and hematologic studies should be performed in order to detect early manifestations of leukemia and/or lymphoma and initiate treatment promptly. In addition, these results provide one more reason for performing Southern blot analysis for the diagnosis of ATL in young patients.

\section{Funding}

This study was supported by the National Research Council (CNPq) and the Bahia State Foundation for the Support of Research (FAPESB). ALB is senior CNPq investigator.

\section{Competing interests}

The authors declare that there are no competing interests.

\section{Ethical approval}

The work was conducted with integrity and in the line with accepted ethical principles. Also, steps were taken to protect patient privacy and confidentiality. Informed consent, in which sampling was first clearly explained to the patient, was obtained. Blood and tissue samples taken during follow-up for histological and virological examination was performed according to the standardized protocol previously approved by local ethics committee.

\section{Acknowledgments}

We are grateful to Prof. Kunihiro Tsukasaki for the revision of the manuscript and Prof. Shimeru Kamihira for assisting Southern blot technique implementation.

\section{References}

1. Bittencourt AL, da Gracas Vieira M, Brites CR, Farre L, Barbosa HS. Adult T-cell leukemia/lymphoma in Bahia, Brazil: analysis of prognostic factors in a group of 70 patients. Am J Clin Pathol 2007;128:875-82.

2. Farre L, de Oliveira MF, Primo J, Vandamme AM, Van Weyenbergh J, Bittencourt AL. Early sequential development of infective dermatitis, human $\mathrm{T}$ cell lymphotropic virus type 1-associated myelopathy, and adult $\mathrm{T}$ cell leukemia/lymphoma. Clin Infect Dis 2008;46:440-2.

3. Hanchard B, LaGrenade L, Carberry C, Fletcher V, Williams E, Cranston B, et al Childhood infective dermatitis evolving into adult T-cell leukaemia after 17 years. Lancet 1991;338:1593-4.

4. Mahe A, Meertens L, Ly F, Sow PS, Diop CT, Samb ND, et al. Human T-cell leukaemia/lymphoma virus type 1-associated infective dermatitis in Africa: a report of five cases from Senegal. Br J Dermatol 2004;150:958-65.

5. Ehrlich GD, Greenberg S, Abbott MA. Detection of human T-cell lymphoma/leukemia viruses. In: Innis MA, Gelfand DH, Sninsky JJ, White TJ, editors. PCR protocols, a guide to methods and applications. San Diego: Academic Press; 1990. p. 325-36.

6. Jennings CD, Foon KA. Recent advances in flow cytometry: application to the diagnosis of hematologic malignancy. Blood 1997;90:2863-92.

7. Boenish T. Immunochemical staining methods. Carpinteria: Dako Corporation; 1989.

8. Kamihira S, Sugahara K, Tsuruda K, Minami S, Uemura A, Akamatsu N, et al. Proviral status of HTLV-1 integrated into the host genomic DNA of adult T-cell leukemia cells. Clin Lab Haematol 2005;27:235-41.

9. Usui T, Yanagihara K, Tsukasaki K, Murata K, Hasegawa H, Yamada Y, et al. Characteristic expression of HTLV-1 basic zipper factor (HBZ) transcripts in HTLV-1 provirus-positive cells. Retrovirology 2008;5:34.

10. Sakashita A, Hattori T, Miller CW, Suzushima H, Asou N, Takatsuki K, et al. Mutations of the p53 gene in adult T-cell leukemia. Blood 1992;79:477-80.

11. Hatta Y, Yamada Y, Tomonaga M, Miyoshi I, Said JW, Koeffler HP. Microsatellite instability in adult T-cell leukaemia. Br J Haematol 1998;101: $341-4$. 
12. LaGrenade L, Hanchard B, Fletcher V, Cranston B, Blattner W. Infective dermatitis of Jamaican children: a marker for HTLV-I infection. Lancet 1990;336: 1345-7.

13. Shimoyama M. Diagnostic criteria and classification of clinical subtypes of adult T-cell leukaemia-lymphoma. A report from the Lymphoma Study Group (1984-87). Br J Haematol 1991;79:428-37.

14. de Oliveira Mde F, Fatal PL, Primo JR, da Silva JL, Batista Eda S, Farre L. Infective dermatitis associated with human T-cell lymphotropic virus type 1: evaluation of 42 cases observed in Bahia, Brazil. Clin Infect Dis 2012;54: 1714-9.
15. Tsukasaki K, Hermine O, Bazarbachi A, Ratner L, Ramos JC, Harrington Jr W, et al Definition, prognostic factors, treatment, and response criteria of adult T-cell leukemia-lymphoma: a proposal from an international consensus meeting. $J$ Clin Oncol 2009;27:453-9.

16. Bittencourt AL, Barbosa HS, Vieira MD, Farre L. Adult T-cell leukemia/lymphoma (ATL) presenting in the skin: clinical, histological and immunohistochemica features of 52 cases. Acta Oncol 2009;48:598-604.

17. de Oliveira MF, Vieira MG, Primo J, Siqueira IC, Carvalho EM, Farre L, et al. Flower cells in patients with infective dermatitis associated with HTLV-1. J Clin Virol 2010;48:288-90. 